\title{
Ethnic Disparities in Contraceptive Use and its Impact on Family Planning Program in Nepal
}

\author{
Mishra MK \\ Department of Social Science, NIMS College, Lalitpur, Nepal
}

\begin{abstract}
Aims: Regardless of three decades of implementation of family planning program in Nepal, need of family planning services is largely unmet. Systematic studies, evaluating the impact of family planning program on several ethnic groups of Nepal has not been carried out in large scale. This study sheds light on the investigation of, whether the use of contraceptives varies among different ethnic groups in Nepal and what are the predictors of contraceptive variance in ethnic groups in Nepal.

Methods: The study is based on data collected from Nepal Demographic Health Survey (NDHS) 2006. Multilevel logistic regression analyses of 10793 married women of reproductive age nested within 264 clusters from the surveys were considered as the sample size. Individual, household, and program variables were set and a multilevel logistic regression model was fitted to analyze the variables, using GLLAMM command in STATA-9.

Results: Multilevel logistic regression analysis indicated that Muslims, Dalits and Terai Madheshi women were significantly less likely to use modern contraceptives compared to the Brahmins and Chhetries (Higher Castes). Women who were exposed to family planning information on radio were more likely to use modern contraceptives than women not exposed to radio information $(\mathrm{OR}=1.22, \mathrm{P}>0.01)$. An odd of using contraceptives by Newars was (OR 1.09, P>0.05), the highest among all ethnic groups. Exposure of women to family planning messages through health facilities, family planning workers and means of communication, increased the odds of using modern contraceptives. However, impact of the family planning information on contraceptive use varied among ethnicity.

Conclusions: Special attention needs to be paid, in particular to the ethnicity, while formulating family planning policies in Nepal, for better success rate of family planning intervention programs.
\end{abstract}

Keywords: Ethnic groups, family planning, modern contraceptives, odd ratio

\section{INTRODUCTION}

Family planning activities were initiated first in 1958 by Nepal Family Planning Association in Nepal. Family Planning Policy was adopted in 1965 and limited family planning services were made available in Kathmandu valley in 1968. Services were expanded all over the country only in the early 1990s. ${ }^{1}$ Various interventions were implemented through the static and mobile services, door-to-door campaigns and mass media to increase knowledge, acceptability and use of contraceptives over the last two decades. As a result, total fertility rate (TFR) has been declined from 5.1 in 1991 to 3.1 in 2006 and the knowledge of family planning is almost universal in Nepal. ${ }^{2}$ It is evident that the need for family planning is largely unmeet $(25 \%){ }^{3}$ Unmet need of contraceptive is considerably higher among poor than wealthier women. Regional and ethnic disparities also exist in the utilization of family planning services. A report on the further analysis of NDHS 2007 indicates that, despite impressive progress on meeting the Millennium Development Goal (MDG), Dalit and Janjati (low castes),

\section{CORRESPONDENCE}

Dr. Mukesh Kumar Mishra, M. Phil

Department of Social Science

NIMS College, Lalitpur-6, Bagmati, Nepal

Phone : 9841363149

Email :mr.callmishra@gmail.com and Terai/Madhesi-origin groups are still facing many barriers to access the family planning services because of their illiteracy, poverty and low social status. ${ }^{4}$

Existing studies on contraceptive use focused more on individual and household level determinants and ignored the importance of community and health care program factors. ${ }^{5,6,7}$ Previous studies have also shown that contraceptive use pattern vary among ethnic groups. ${ }^{8,9,10}$

Exposure to message broadcast through a variety of channels is currently considered as the most effective way of changing knowledge, attitudes and behaviour. ${ }^{11}$ Conceptual framework developed by Bertrand et al. (1996) ${ }^{12}$ provides the basis to evaluate the impact of family planning program. The framework recognizes that fertility and other behaviour are consequences of both the demand for and supply of family planning services. Demand for family planning services are affected by a number of political, socioeconomic, cultural and individual factors. Thus an increase in the availability of family planning services is more likely to translate into higher 
levels of use in a country where these other factors exert a positive influence on demand.

So far, systematic studies using this framework for evaluating the impact of family planning program on the utilization of contraceptive services among different ethnic groups have not been conducted in Nepal. This analysis intends to fill up this gap by examining the differences of the impact of exposure to family planning services on the modern contraceptive use among different ethnic groups.

Overall objective of this study is to examine whether observed differences in the levels of modern contraceptive use among different ethnic groups over the last ten years in Nepal is associated with the exposure to family planning information. More specifically, this study intends to examine:

a) Whether the impact of exposure to family information on contraceptive use varies among different ethnic groups controlling for individual, household and program level characteristics

b) What are the predictors of ethnic variance in contraceptive use in Nepal? and

c) To what extent, do they impact on family planning services in Nepal?

\section{METHODS}

Individual, household, and program-level data for this analysis came from Nepal Demographic and Health Surveys 2006. Altogether 10,793 married women of reproductive age nested with 264 clusters from the survey was considered as sample size. Proportionate to population size (PPS) equal weighting cluster approach was followed to determine the number of clusters. The $95 \%$ two-sided $\mathrm{t}$-value with 10-1 degrees of freedom was 2.2621. A multilevel logistic regression model was fitted to analyze the use of modern contraceptives by six ethnic groups of Nepal based on individual, household and program level variable, using GLLAMM command in STATA-9.

The individual variables were chosen to represent sociodemographic factors that previous research had shown to be associated with contraceptive use: age, education and place of residence. In the absence of information on household income, a wealth index was used to represent the socioeconomic status of the household. The index included the ownership of household amenities and goods: telephone, electricity, radio, television, bicycle, floor (vinyl or Asphalt strips, carpet, tile, concrete, wood), piped water, and flush toilet. The family planning program related variables include, whether or not a woman was visited by family planning worker during last 12 months, visited health facilities during the last 12 months and heard family planning on radio.
The analysis used a cumulative approach to model building. Model 1 is a null model which was run without including any variables. Model 2 includes only the year of survey. Model 1 and 2 were not significant to this study thus they were ignored. Model 3 included individual factors. Model 4 included individual and household factors and Model 5 included individual, household and program level factors. This approach allowed the identification of the relative impact of each set of factors in explaining community variation in the contraceptive use. All models included cluster-level random effects terms.

\section{RESULTS}

\section{Sample characteristics}

In this study among married women of reproductive age, $36 \%$ used the modern contraceptives and $55.4 \%$ were in the 20-34 years age group. Seventy-two percent of women had no education, whereas $14 \%$ had a secondary or higher level of education. The largest ethnic groups were the upper castes Brahmins and Chhetries (32\%), Janjatis (30\%), Terai Madhesi castes (15\%), Dalits (13\%), Newars (5\%) and Muslims (5\%) (Table 1).

Table 1. Distribution of married women aged 15-49 used in the analysis by selected characteristics

\begin{tabular}{|c|c|c|}
\hline \multirow{3}{*}{$\begin{array}{l}\text { Characteristics } \\
\text { Modern } \\
\text { Contraceptive Use }\end{array}$} & & $(\%)$ \\
\hline & ----------- & 36.0 \\
\hline & & \\
\hline \multirow[t]{3}{*}{ Age } & Below 20 & 9.9 \\
\hline & $20-34$ & 55.4 \\
\hline & 35 and over & 34.7 \\
\hline \multirow[t]{3}{*}{ Education } & No & 71.7 \\
\hline & Primary & 14.1 \\
\hline & Secondary and above & 14.2 \\
\hline \multirow[t]{6}{*}{ Ethnicity } & Brahmin/Chhetri & 31.6 \\
\hline & Terai Madhesi other cast & 15.4 \\
\hline & Dalit & 13.4 \\
\hline & Newar & 5.0 \\
\hline & Janjatis & 30.0 \\
\hline & Muslim & 4.6 \\
\hline \multirow[t]{2}{*}{ Residence } & Rural & 89.2 \\
\hline & Urban & 10.8 \\
\hline \multirow{5}{*}{$\begin{array}{l}\text { Household socio- } \\
\text { economic status }\end{array}$} & Poorest & 30.4 \\
\hline & Poorer & 14.4 \\
\hline & Middle & 17.5 \\
\hline & Richer & 20.0 \\
\hline & Richest & 17.7 \\
\hline $\begin{array}{l}\text { Visited by health } \\
\text { worker }\end{array}$ & --------- & 9.8 \\
\hline $\begin{array}{l}\text { Visited health } \\
\text { facility }\end{array}$ & -------- & 48.1 \\
\hline $\begin{array}{l}\text { Heard family } \\
\text { planning on radio }\end{array}$ & -------- & 57.6 \\
\hline
\end{tabular}




\section{Contraceptive Use}

Among the 23,381 currently married women of reproductive age, 36\% reported to use modern contraceptives (Table 1 ). Among the $36 \%$ women who were currently using contraceptive, 9.0\% were below the age 20, $35 \%$ were illiterate and $53 \%$ were urban residences. The variation in use of modern contraceptives was seen among the ethnic groups, 39\% Bramhins/Chhetries, 34\% Terai Madheshi, $29 \%$ Dalits, 52\% Newars, $38 \%$ Janjatis and 13\% Muslim women used modern contraceptives (Table 2).

Table 2. Distribution of married women aged 15-49, using modern contraceptive method by selected characteristics

\begin{tabular}{|c|c|c|c|c|c|c|c|}
\hline \multirow{2}{*}{$\begin{array}{l}\text { Charac- } \\
\text { teristics }\end{array}$} & \multicolumn{7}{|c|}{ Ethnic groups in \% } \\
\hline & All & $\mathrm{B}^{*}$ & $\mathrm{~T}^{*}$ & $\mathrm{D}^{*}$ & $\mathbf{N}^{*}$ & J* & $\mathbf{M}^{*}$ \\
\hline \multicolumn{8}{|l|}{ Age } \\
\hline Below 20 & 9.0 & 9.0 & 4.9 & 5.9 & 20.9 & 13.6 & 6.3 \\
\hline $20-34$ & 44.4 & 36.1 & 31.7 & 26.2 & 49.4 & 38.0 & 12.4 \\
\hline over & 46.2 & 50.1 & 47.9 & 44.4 & 61.5 & 43.8 & 16.2 \\
\hline $\begin{array}{l}\text { Ethnic groups } \\
\text { using modern } \\
\text { contra } \\
\text { ceptives }\end{array}$ & - & 38.8 & 34.0 & 28.8 & 52.2 & 38.0 & 13.0 \\
\hline \multicolumn{8}{|l|}{ Education } \\
\hline No & 34.5 & 36.8 & 33.4 & 28.3 & 51.8 & 38.7 & 11.1 \\
\hline Prima & 38.1 & 40.7 & 33.0 & 33.3 & 52.7 & 37.4 & 16.6 \\
\hline $\begin{array}{l}\text { Secondary } \\
\text { and above }\end{array}$ & 41.1 & 42.3 & 43.1 & 34.3 & 52.2 & 33.1 & 43.2 \\
\hline \multicolumn{8}{|l|}{ Residence } \\
\hline Rural & 33.8 & 36.1 & 32.5 & 27.4 & 44.7 & 37.2 & 11.0 \\
\hline Urban & 53.7 & 56.1 & 50.8 & 45.7 & 65.7 & 48.5 & 32.2 \\
\hline \multicolumn{8}{|c|}{ Household socio-economic status } \\
\hline Poorest & 24.5 & 23.6 & 26.2 & 22.3 & 23.2 & 28.4 & 7.3 \\
\hline Poorer & 32.3 & 31.7 & 34.1 & 28.0 & 33.8 & 35.7 & 12.0 \\
\hline Middle & 36.8 & 40.8 & 37.6 & 35.1 & 28.0 & 41.0 & 11.2 \\
\hline Richer & 40.4 & 42.7 & 38.1 & 35.6 & 47.1 & 43.8 & 14.7 \\
\hline Richest & 52.9 & 55.6 & 45.1 & 49.3 & 65.7 & 46.4 & 32.3 \\
\hline $\begin{array}{l}\text { Visited by } \\
\text { health worker }\end{array}$ & 49.1 & 50.0 & 43.4 & 40.2 & 70.8 & 53.3 & 35.3 \\
\hline $\begin{array}{l}\text { Visited health } \\
\text { facility }\end{array}$ & 39.6 & 41.4 & 34.0 & 29.9 & 56.3 & 43.5 & 19.7 \\
\hline $\begin{array}{l}\text { Heard family } \\
\text { planning on } \\
\text { radio }\end{array}$ & 40.7 & 41.6 & 44.7 & 31.3 & 52.0 & 41.0 & 22.7 \\
\hline
\end{tabular}

* $\mathrm{B}=$ Brahmin/Chhetri, *T= Terai madhesi other cast, *D=

Dalit, ${ }^{*} \mathrm{~N}=$ Newar, ${ }^{* J}=$ Janjatis, $* \mathrm{M}=$ Muslim

\section{Multilevel Analysis}

Multilevel logistic regression modeling was employed to determine the impact of the program variables on contraceptive use and to examine ethnic differences in their use. Individual and household variables were also included in the model as confounders. Three variables on exposure to family planning information from health workers and mass media sources were used as program variables. Three groups of variables were entered into the model in sequence. Table 3 and Table 4 showed the result of the multilevel modeling of the contraceptive use.

Model 1 is a null model which was run without including any variable. Model 2 includes only the year of survey. Model 1 and 2 were not significant to explain the cluster level variance so they were excluded from the Table. Individual socio-demographic factors included in Model 3 explained $17 \%$ of the cluster-level variation of modern contraceptive use remained unexplained in Model 2. Similarly, household wealth index added in Model 4 explained 19\% of the cluster-level variation of contraceptive use as seen in Model 3. Cluster-level variables obtained by aggregating individual characteristics within the cluster were added in Model 4 , which were able to explain $11 \%$ of the clusterlevel variation of contraceptive use remained unexplained in Model 5. Finally, the program variables were added in the Model 5. The program variables, exposure of family planning message from health workers and media sources added in Model 5 were able to explain that $5 \%$ of the cluster-level variance on contraceptive use remained unexplained in Model 4. Even after controlling for individual, household, cluster and year of survey in Model 5 , significant cluster-level variance in contraceptive use remained unexplained.

Controlling for individual, household and cluster-level factors, all program variables were significantly associated with the modern contraceptive use (Table 3). Currently married women of reproductive age who visited health facilities or who were visited by health worker during the last 12 month were more likely to use modern contraceptive use $(\mathrm{OR}=1.23$ and 1.60 respectively $\mathrm{P}>0.05)$ than women who were not in contact with health workers or health facilities. Likewise, women who were exposed to family planning information in radio in the last few months were more likely to use modern contraceptive use than women not exposed to family planning in these media $(\mathrm{OR}=1.22, \mathrm{P}>0.01)$.

With household (Model 3), cluster (Model 4) and program variables (Model 5) sequentially added, place of residence and ethnicity (Newar and Terai Madhesi) emerged as non-significant predictors of contraceptive use. Model 5 further showed that, all ethnic groups except Newars were significantly less likely to use modern contraceptive than the Brahmin and Chhetries (OR1.09, P> 0.05). 
Table 3. Odd ratios (and 95\% confidence intervals) from multilevel models examining the odds of using modern contraceptive methods by selected characteristics

\begin{tabular}{|c|c|c|c|c|}
\hline Characteristics & & Model 3 (OR) & Model 4(OR) & Model 5(OR) \\
\hline \multirow[t]{3}{*}{ Age } & Below 20 (ref) & 1 & 1 & 1 \\
\hline & $20-34$ & $5.02(4.31-5.85)$ & $4.94(4.24-5.76)$ & $4.88(4.18-5.68)$ \\
\hline & 35 and over & $8.73(7.45-10.24)$ & $8.37(7.14-9.81)$ & 8.18(6.98-9.59) \\
\hline \multirow[t]{3}{*}{ Education } & No (ref) & 1 & 1 & 1 \\
\hline & Primary & $1.07(0.97-1.17)$ & $0.99(0.90-1.10)$ & $0.9(0.90-1.07)$ \\
\hline & Secondary and above & $1.00(0.90-1.11)$ & $0.86(0.77-0.96)$ & $0.85(0.76-0.94)$ \\
\hline \multirow[t]{6}{*}{ Ethnicity } & Brahmin/Chhetri (ref) & 1 & 1 & 1 \\
\hline & Terai Madhesi & $0.85(0.74-0.97)$ & $0.90(0.79-1.03)$ & $0.85(0.74-0.98)$ \\
\hline & Dalit & $0.72(0.64-0.80)$ & $0.81(0.72-0.91)$ & $0.79(0.71-0.89)$ \\
\hline & Newar & $1.21(1.03-1.43)$ & $1.18(1.00-1.39)$ & $1.09 *(0.92-1.29)$ \\
\hline & Janjatis & $0.86(0.78-0.94)$ & $0.88(0.81-0.97)$ & $0.86(0.78-0.94)$ \\
\hline & Muslim & $0.27(0.20-0.35)$ & $0.28(0.21-0.37)$ & $0.25(0.19-0.33)$ \\
\hline \multirow[t]{2}{*}{ Residence } & Rural (ref) & 1 & 1 & 1 \\
\hline & Urban & $2.02 *(1.71-2.39)$ & $1.53 *(1.30-1.80)$ & $0.95 *(0.79-1.15)$ \\
\hline \multirow{5}{*}{$\begin{array}{l}\text { Household socio-economic } \\
\text { status }\end{array}$} & Poorest (ref) & & 1 & 1 \\
\hline & Poorer & & $1.26(1.14-1.40)$ & 1.25 (1.13-1.39) \\
\hline & Middle & & $1.66(1.50-1.84)$ & $1.60(1.45-1.77)$ \\
\hline & Richer & & 1.78 (1.61-1.97) & $1.67(1.50-1.84)$ \\
\hline & Richest & & $2.50(2.21-2.84)$ & $2.08(1.82-2.38)$ \\
\hline \multirow[t]{2}{*}{ Visited by health worker } & No (ref) & & & 1 \\
\hline & Yes & & & $1.6 *(1.44-1.76)$ \\
\hline \multirow[t]{2}{*}{ Visited health facility } & No (ref) & & & 1 \\
\hline & Yes & & & $1.23 *(1.15-1.32)$ \\
\hline \multirow[t]{2}{*}{ Heard family planning on radio } & No (ref) & & & 1 \\
\hline & Yes & & & $1.22 * *(1.12-1.32)$ \\
\hline
\end{tabular}

*Significant at 0.05

significant at 0.01

$\mathrm{B} \#=$ Brahmin/Chhetri, $\mathrm{T} \#=$ Terai madhesi other cast, $\mathrm{D \# =}$ Dalit, N\#= Newar, J\#= Janjatis, M\#= Muslim *Significant at $0.05^{* *}$ significant at 0.01

Place of residence, which was significant predictor of modern contraceptive use in Model 3 also emerged as non-significant when cluster and program factors were added in Model 4 and Model 5. The odd ratio for urban area has decreased in Model 4 and 5 as the cluster and program variables added to model (OR of Urban area in model 3,4 , and 5 is $2.02,1.23$, and 0.95 respectively with P> 0.05).

Table 4 showed the results of the multilevel logistic regression models of the modern contraceptive use among the 6 ethnic groups separately. None of the program variables proved to be significantly associated with the contraceptive use in all 6 ethnic groups. The health worker's visit showed a significant association with contraceptive use in all ethnic groups except in Newars. Women belonging to Brahmin and Chhetries, Newars, Janjatis and Muslims, who visited health facilities during the last 12 months, were more likely to receive modern contraceptive use than the women who did not visit health facilities during thesameperiod. Relativetowomen who did notheard family planning information from radio, all women (except Newars, Janjatis and Muslims) who heard family planning message from radio were more likely to use contraceptive.

There was also ethnic variation in the association of place of residence, Janjati and Muslim women living in urban sectors were more likely to use modern contraception (OR 1.11 and 1.24 respectively with $P>0.05$ ) than their rural counterpart. Level of education did not fit significantly to modern contraception use among Dalit women, women with primary education had better odd ratio than women with secondary or above education( OR 0.95 and 0.82 respectively with $\mathrm{p}>0.5$ and 0.01 ).

There was also ethnic variation in the association of household wealth with the contraceptive use; household wealth was not associated with contraceptive use in Muslims. The visit by health workers was found very high among Muslims (OR 4.0 with $P>0.05$ ) and very low among Terai Madheshi women (OR 1.47 with P>0.05). Similarly, Ethnic groups except Newars were found significantly associated with information on family planning through radio. 
Table 4. Odd ratios (and 95\% confidence intervals) from multilevel models examining the odds of using modern contraceptive methods by ethnic groups and selected variables, 2006

\begin{tabular}{|c|c|c|c|c|c|c|}
\hline \multirow[t]{2}{*}{ Characteristics } & \multicolumn{6}{|c|}{ Final Multilevel Model by Ethnicity } \\
\hline & B\# & T\# & D\# & N\# & J\# & M\# \\
\hline \multicolumn{7}{|l|}{ Age } \\
\hline Below 20 (ref) & 1 & 1 & 1 & 1 & 1 & 1 \\
\hline $20-34$ & $\begin{array}{l}4.83 \\
(3.66-6.38)\end{array}$ & $\begin{array}{l}10.46 \\
(5.88-18.61)\end{array}$ & $\begin{array}{l}5.60 \\
(3.65-8.57)\end{array}$ & $\begin{array}{l}2.79 \\
(1.49-5.25)\end{array}$ & $\begin{array}{l}3.98 \\
(3.05-5.19)\end{array}$ & $\begin{array}{l}2.14 \\
(0.84-5.41)\end{array}$ \\
\hline 35 and over & $\begin{array}{l}9.11 \\
(6.83-12.15)\end{array}$ & $\begin{array}{l}21.07 \\
(11.70-37.95)\end{array}$ & $\begin{array}{l}14.2 \\
(9.14-22.18)\end{array}$ & $\begin{array}{l}4.63 \\
(2.38-9.01)\end{array}$ & $\begin{array}{l}5.88 \\
(4.45-7.78)\end{array}$ & $\begin{array}{l}2.89 \\
(1.10-7.61)\end{array}$ \\
\hline \multicolumn{7}{|l|}{ Education } \\
\hline No (ref) & 1 & 1 & 1 & 1 & 1 & 1 \\
\hline Primary & $\begin{array}{l}0.90 \\
(0.77-1.05)\end{array}$ & $\begin{array}{l}0.84 \\
(0.61-1.17)\end{array}$ & $\begin{array}{l}0.95 * \\
(0.70-1.29)\end{array}$ & $\begin{array}{l}0.70 \\
(0.48-1.01)\end{array}$ & $\begin{array}{l}0.93 \\
(0.78-1.11)\end{array}$ & $\begin{array}{l}1.13 \\
(0.42-3.04)\end{array}$ \\
\hline Secondary and above & $\begin{array}{l}0.73 \\
(0.61-0.87)\end{array}$ & $\begin{array}{l}0.90 \\
(0.59-1.36)\end{array}$ & $\begin{array}{l}0.82 * * \\
(0.49-1.35)\end{array}$ & $\begin{array}{l}0.45 \\
(0.29-0.69)\end{array}$ & $\begin{array}{l}0.73 \\
(0.57-0.93)\end{array}$ & $\begin{array}{l}1.22 \\
(0.44-3.38)\end{array}$ \\
\hline \multicolumn{7}{|l|}{ Residence } \\
\hline Rural (ref) & 1 & 1 & 1 & 1 & 1 & 1 \\
\hline Urban & $\begin{array}{l}0.86 \\
(0.67-1.12)\end{array}$ & $\begin{array}{l}0.76 \\
(0.43-1.31)\end{array}$ & $\begin{array}{l}0.88 \\
(0.60-1.30)\end{array}$ & $\begin{array}{l}0.78 \\
(0.49-1.27)\end{array}$ & $\begin{array}{l}1.11^{*} \\
(0.80-1.53)\end{array}$ & $\begin{array}{l}1.24^{*} \\
(0.39-3.95)\end{array}$ \\
\hline \multicolumn{7}{|c|}{$\begin{array}{l}\text { Household socio-economic } \\
\text { status }\end{array}$} \\
\hline Poorest (ref) & 1 & 1 & 1 & 1 & 1 & 1 \\
\hline Poorer & $\begin{array}{l}1.27 \\
(1.07-1.51)\end{array}$ & $\begin{array}{l}1.26 \\
(0.88-1.78)\end{array}$ & $\begin{array}{l}1.30 \\
(0.98-1.71)\end{array}$ & $\begin{array}{l}1.45 \\
(0.72-2.93)\end{array}$ & $\begin{array}{l}0.93 \\
(0.77-1.12)\end{array}$ & $\begin{array}{l}1.34 \\
(0.45-3.96)\end{array}$ \\
\hline Middle & $\begin{array}{l}1.66 \\
(1.37-2.00)\end{array}$ & $\begin{array}{l}1.87 \\
(1.45-2.41)\end{array}$ & $\begin{array}{l}1.74 \\
(1.32-2.29)\end{array}$ & $\begin{array}{l}1.41 \\
(0.74-2.69)\end{array}$ & $\begin{array}{l}1.23 \\
(1.02-1.48)\end{array}$ & $\begin{array}{l}1.20 \\
(0.61-2.38)\end{array}$ \\
\hline Richer & $\begin{array}{l}1.59 \\
(1.32-1.91)\end{array}$ & $\begin{array}{l}1.48 \\
(1.12-1.97)\end{array}$ & $\begin{array}{l}1.61 \\
(1.19-2.20)\end{array}$ & $\begin{array}{l}2.51 \\
(1.37-4.60)\end{array}$ & $\begin{array}{l}1.39 \\
(1.15-1.67)\end{array}$ & $\begin{array}{l}1.33 \\
(0.65-2.70)\end{array}$ \\
\hline Richest & $\begin{array}{l}2.03 \\
(1.60-2.58)\end{array}$ & $\begin{array}{l}1.83 \\
(1.21-2.76)\end{array}$ & $\begin{array}{l}1.88 \\
(1.17-3.01)\end{array}$ & $\begin{array}{l}3.28 \\
(1.64-6.58)\end{array}$ & $\begin{array}{l}1.47 \\
(1.15-1.88)\end{array}$ & $\begin{array}{l}2.48 \\
(0.97-6.36)\end{array}$ \\
\hline \multicolumn{7}{|c|}{ Visited by health worker } \\
\hline No (ref) & 1 & 1 & 1 & 1 & 1 & 1 \\
\hline Yes & $\begin{array}{l}1.59 \\
(1.34-1.89)\end{array}$ & $\begin{array}{l}1.47^{*} \\
(1.10-1.97)\end{array}$ & $\begin{array}{l}1.82 \\
(1.35-2.47)\end{array}$ & $\begin{array}{l}1.58 \\
(0.91-2.72)\end{array}$ & $\begin{array}{l}1.58 \\
(1.33-1.89)\end{array}$ & $\begin{array}{l}4.00 * \\
(2.07-7.75)\end{array}$ \\
\hline \multicolumn{7}{|l|}{ Visited health facility } \\
\hline No (ref) & 1 & 1 & 1 & 1 & 1 & 1 \\
\hline Yes & $\begin{array}{l}1.13 \\
(1.01-1.26)\end{array}$ & $\begin{array}{l}0.86 \\
(0.71-1.04)\end{array}$ & $\begin{array}{l}0.99 \\
(0.81-1.20)\end{array}$ & $\begin{array}{l}1.64 \\
(1.23-2.17)\end{array}$ & $\begin{array}{l}1.57 \\
(1.39-1.77)\end{array}$ & $\begin{array}{l}2.18 \\
(1.33-3.59)\end{array}$ \\
\hline \multicolumn{7}{|c|}{ Heard family planning on radio } \\
\hline No (ref) & 1 & 1 & 1 & 1 & 1 & 1 \\
\hline Yes & $\begin{array}{l}1.29 \\
(1.12-1.48)\end{array}$ & $\begin{array}{l}1.53 \\
(1.20-1.95)\end{array}$ & $\begin{array}{l}1.06 \\
(0.85-1.31)\end{array}$ & $\begin{array}{l}0.86 \\
(0.61-1.22)\end{array}$ & $\begin{array}{l}1.23 \\
(1.07-1.42)\end{array}$ & $\begin{array}{l}1.29 \\
(0.73-2.29)\end{array}$ \\
\hline
\end{tabular}

\section{DISCUSSION}

Findings from this analysis indicated that age and ethnicity were the important individual-level factors contributing to the contraceptive use. All the program variables used in the analyses were associated with increased contraceptive use. Exposure to family planning information on radio and contact of women with the health workers were the important program variables contributing to contraceptive adoption.
Impact of the program variables on contraceptive use differed by ethnicity. For example, health worker's visit was not associated with contraceptive use among Newars. Similarly there was no association between health facility visit and contraceptive use among Dalits and Terai Medhesi ethnic groups. While, exposure to family planning information through radio was not associated with contraceptive use among Newars, Janjatis and Muslims. 
This analysis also indicated that the household economic status was strong predictor of contraceptive use behavior, though its impact of on contraceptive use varies by the ethnicity. Large scale studies conducted in Sweden, Turkey, Poland and Iran showed strong association between ethnicity and poor self reported health which was mediated by socioeconomic status, cultural change, and discrimination. ${ }^{13,14}$ It is also found that large percentages of Muslim women failed to use modern contraceptive and the trend was not so encouraging in the last decade. The question why so large proportion of Muslims are not using contraceptive should be the issue of further exploration. However, we can speculate that this may be due to the language, cultural barrier and their feeling of discrimination, which need to be addressed by family planning program.

It is also evident that despite geographical and cultural difficulties, ethnic minority groups can be open to adopt family planning when services are accessible and provided in a culturally acceptable manner. ${ }^{12}$ Therefore, future family planning program intervention in Nepal should be planned to make it context specific so as to make it acceptable in different cultures. Different approaches should be applied to expand the family planning program in Mountain, Hill and Terai regions and among different ethnic groups. It is also speculated that the ethnic variation in contraceptive use is due to the cultural or knowledge barriers affecting women's access to health care in Nepal. Therefore, ethnic minorities should be made more aware with the importance of the family planning programs. Special program attention should be made to the Muslim, Dalit and Madhesi women.

Finally, the interventions to be designed in the future in Nepal to attain millennium development goal (MDG) should be based on socio-cultural conditions of different ethnic groups. The community health workers including female community health volunteers (FCHV) should be encouraged to disseminate health information in local language. They should also be motivated to serve Dalits, Muslims and other ethnic minorities without violating the local cultural norms. Members of the local ethnic groups should be integrated in the working team to deliver the family planning message among Muslim, Terai Madhesi and Dalits.

\section{REFERENCES}

1. Aryal RH, Pathak RS, Dottel BR, Pant PD. A comparative analysis of unmeet need in Nepal: further analysis of the 2006 Nepal Demographic and Health Survey. Calverton Maryland USA:, Macro International Inc 2008.

2. Nepal Demographic and Health Survey, 2006. Ministry of Health and Population (MoHP) Nepal, New Era, and Macro International Inc.

3. Karki YB, Krishna R. Factors responsible for the rapid decline of fertility in Nepal-an interpretation: Analysis of the 2006 Nepal Demographic and Health Survey. Calverton, Maryland, USA: Macro International Inc. 2008.

4. Bennett L, Dahal DR. Caste/ethnic and regional identity dimensions of the 2006 Nepal, Demographic and Health Survey. Calverton, Maryland, USA: Macro International Inc. 2008.

5. Dahal GP, Padmadas SS, Andrew-Hide PR. Fertility-limiting behavior and contraceptive choice among men in Nepal. International Family Planning Perspective 2008; 34(1):6-14

6. Emens A. Perceived fertility regulation costs and contraceptive use in Nepal. Population Studies Center Research Report Michigan University 2008; 08-644

7. Sharan M, Valente TW. Spousal communication and family planning adoption: effects of a radio drama serial in Nepal. Int Fam Plan Perspect 2002; 28(1): 16-25.

8. Christman SK, Zawacki T. Understanding ethnic disparities in Contraceptive Use: The mediating role of attitudes. Under Graduate Research Journal for the Human Science 2009; 8.

9. Raine, T, Harper C, Paukku M, Darney P. Race, adolescent contraceptive choice, and pregnancy at presentation to a family Planning clinic. Obstetrics and Gynecology 2002; 99(2): 241-247.

10. Addai I. Ethnicity and contraceptive use in sub-Saharan Africa: the case of Ghana. Journal of Biosocial Science 1999; 31(1):105-20.

11. Gupta N, Katende C, abd Bessinger R. Association of mass media exposure with family planning attitudes and practices in Uganda. Studies in Family Planning 2003; 34(1):19-31

12. Bertrand JT, Seiber E Escudero G.. Contraceptive dynamics in Guatemala: 1978-1998. International Family Planning Perspectives 2001; 27(3): 112-118.

13. Wiking E, Joshansson S, Sundquist J. Ethnicity, acculturation, and self reported health. A population based study among immigrants from Poland, Turkey, and Iran. Sweden Journal of Epidemiol Community Health 2003; 58: 574-582.

14. Lindstrom $M$, Sundquist J, Ostergren PO.. Ethnic differences in self-reported health in Malmo in Southern Sweden. J Epidemiol Community Health 2001; 55: 97-103 